\title{
Pengembangan Bahan Ajar Transformasi Geometri Berorientasi pada Kemampuan Bepikir Kritis Siswa
}

\section{Mateus Diki Destino', Haninda Bharata², dan Caswita ${ }^{3}$}

1,2,3 Universitas Lampung, Bandar Lampung, Indonesia

Corresponding Author: mtsdestino@gmail.com ${ }^{1}$

DOI: http://dx.doi.org/10.15294/kreano.v10i1.18493

Received : March 2019; Accepted: May 2019; Published: June 2019

\begin{abstract}
Abstrak
Penelitian ini bertujuan untuk mengembangkan bahan ajar transformasi geometri yang berorientasi pada kemampuan berpikir kritis siswa. Penelitian ini merupakan penelitian pengembangan yang mengikuti tahapan R\&D (Brog \& Gall, 1989). Ujicoba lapangan dilakukan pada siswa kelas XI SMA Fransiskus Bandar Lampung tahun pelajaran 2018/2019, dengan XI-A1 sebagai kelas eksperimen dan kelas XI-A3 sebagai kelas kontrol. Perbedaan perlakuan dari kedua kelas adalah penggunaan bahan ajar transformasi geometri. Pengumpulan data menggunakan lembar validasi untuk menentukan validitas bahan ajar, angket respon siswa dan praktisi untuk menentukan tingkat kepraktisan dan instrumen tes kemampuan berpikir ktitis siswa untuk menentukan kefektifan bahan ajar setelah pembelajaran yang kemudian dianalisis dengan uji perbedaan rata-rata. Hasil penelitian ini adalah pengembangan bahan ajar tranformasi geometri yang dikembangkan valid, praktis, dan efektif.
\end{abstract}

\begin{abstract}
This research was aimed to develop a geometry transformation learning material that is oriented to students' critical thinking ability. This research was an development research that followed R\&D stages (Brog \& Hall, 1989) until the main field test. The field-testing was conducted on grade XI students of SMA Fransiskus Bandar Lampung academic year 2018/2019 where XI-A1 was chosen as the experiment class and XI-A3 as the control class. The difference in treatment between these two classes was in the using of the geometry transformation learning material. Data were collected using the validation sheet to determine the validity level, the students' response questionnaire to determine the practicality level, and the students' critical thinking ability test instrument to determine the effectivity of the learning material after the learning process. Afterwards, data were analyzed by the difference in mean test. It can be concluded from the research result that the developed geometry transformation learning material was valid, practical, and effective.
\end{abstract}

Keywords: critical thinking; learning material

\section{PENDAHULUAN}

Pendidikan merupakan salah satu faktor yang sangat penting untuk meningkatkan kualitas sumber daya manusia. Untuk itu, infrastruktur yang terkait dalam dunia pendidikan sebaiknya tersusun secara konstruktif dan sistematis sehingga dapat menghasilkan produk pendidikan yang bermutu dan sesuai dengan kebutuhan. Dalam menyiapkan sumber daya manusia yang berkualitas perlu di- bekali dengan kemampuan berpikir kritis, karena kemampuan tersebut dibutuhkan dalam memperoleh, mengelola, dan memanfaatkan informasi untuk bertahan hidup pada keadaan yang selalu berubah, tidak pasti, dan kompetitif. Untuk menunjang hal tersebut diperlukan peningkatan kualitas pendidikan disemua aspek, salah satunya dalam pembelajaran matematika. Menurut BNSP (Depdiknas, 2006) mata pelajaran matematika bertujuan untuk 
membekali siswa dengan kemampuan berpikir logis, analitis, sistematis, kritis, dan kreatif, serta kemampuan bekerjasama. Berdasarkan uraian tersebut jelas bahwa kemampuan berpikir berpikir kritis merupakan bagian dari tujuan pembelajaran matematika (Liberna, 2015).

Pembelajaran matematika dilihat dari beberapa hasil penelitian internasional dalam hal prestasi matematika siswa, Programme for International Student Assessment (PISA). Pada tahun 2015, prestasi siswa Indonesia dalam matematika berdasarkan (PISA) pada urutan ke 63 dari 70 partisipan dengan poin 386 yang jauh di bawah skor rata-rata OECD yakni 490. Sejalan dengan hasil PISA 2015, hasil ujian nasional 2018 memberikan gambaran kemampuan matematika siswa SMA di Indonesia yang masih rendah dengan ratarata nilai 36,46 pada program IPA, 32,72 pada program IPS dan 35,00 pada program Bahasa. Hasil ujian nasional mata pelajaran matematika siswa SMA Fransiskus Bandar Lampung tahun ajaran 2017/2018 memperoleh pencapaian 39,86 pada program IPA dan 57,88 pada program IPS yang masih tergolong rendah. Berdasarkan hasil pengumpulan data yang dilakukan di SMA Fransiskus, diperoleh data bahwa $70 \%$ siswa kelas XI SMA Fransiskus kesulitan dalam memecahkan masalah cerita. Data ini diperoleh dari hasil ulangan siswa kelas XI SMA Fransiskus pada materi program linear yang menunjukkan bahwa siswa tidak mampu mengerjakan butir soal cerita dengan baik. Mereka mampu mengerjakan tipe soal yang sudah pernah dikerjakan atau prosedur pengerjaannya sudah pernah mereka lalui. Tetapi mereka kesulitan dalam membuat model matematika disaat ilustrasi soal berbeda dengan yang sudah pernah dikerjakan. Permasalahan yang muncul adalah kesulitan siswa dalam memecahkan soal yang tidak rutin atau soal-soal yang proses pemecahanya belum pernah dilalui oleh siswa. Hal ini terjadi karena kurangnya kemampuan berpikir kritis siswa. Kenyataan tersebut menjadi tugas bagi seorang guru matematika untuk terus melakukan perbaikan agar terjadi peningkatan kemampuan berpikir kritis. Karena bagaimana pun kemampuan berpikir kritis dalam pembelajaran matematika merupakan tujuan yang di- kelompokan secara holistik berdasarkan apa arti mengajar, mengerjakan, dan memahami matematika.

Dalam mengembangkan kemampuan berpikir kritis siswa menurut Maulana (2017) dibutuhkan kondisi sebangai berikut. (1) Situasi yang tidak familiar, dalam hal ini siswa tidak dapat secara langsung mengetahui bagaimana menentukan solusi dari masalah matematis yang dihadapi. (2) Memberikan kesempatan kepada siswa untuk menggunakan pengetahuan awalnya, melakukan penalaran matematis, dan mencoba strategi kognitif secara fleksibel. (3) Memberikan kesempatan kepada siswa, untuk melakukan generalisasi, pembuktian, dan evaluasi terhadap situasi matematis dan proses pencarian solusi yang telah dilakukannya dengan penuh pertimbangan.

Demi terwujudnya kondisi diatas dan untuk menunjang penyampaian informasi yang lebih baik kepada siswa dalam pembelajaran perlu didukung dengan bahan ajar yang baik dan menarik dapat mempermudah siswa dalam memahami materi yang disampaikan sehingga dapat meningkatkan hasil belajar siswa. Bahan ajar yang berbasis masalah memungkinkan siswa untuk bekerja secara mandiri, serta dari masalah kontektual (berkaitan dengan kehidupan sehari-hari) yang dapat meningkatkan kemampuan berpikir kritis siswa dalam menyelidiki, menemukan dan memecahakan masalah. Budiman et al (2008) menyatakan bahwa bahan ajar yang disusun secara sistematis dengan bahasa yang mudah dipahami oleh siswa sesuai tingkat pengetahuan dan usia mereka, agar mereka dapat belajar secara (mandiri) dengan bantuan atau bimbingan yang minimal dari pendidik. Lebih lanjut Hasruddin (2009) menyatakan bahwa bahan ajar adalah sebuah buku yang ditulis dengan tujuan agar siswa dapat belajar mandiri atau tanpa bantuan guru. Selain membantu siswa dalam menyelesaikan masalah pembelajaran, bahan ajar juga membantu guru dalam menyampaikan indikator pembelajaran yang harus dipahami oleh siswa secara lebih menarik, efektif dan efisien.

Berdasarkan uraian di atas, masalah penelitian difokuskan pada pengembangan 
bahan ajar transformasi geometri yang berorientasi pada kemampuan berpikir kritis siswa. Kualitas bahan ajar ditinjau dari tingkat kevalidan, kepraktisan, dan keefektifan bahan ajar dalam uji lapangan.

\section{METODE}

Produk pengembangan ini berupa bahan ajar transformasi geometri yang berorientasi kemampuan berpikir kritis siswa. Penelitian ini dirancang dengan pendekatan penelitian pengembangan (Borg \& Gall, 1989) yang hanya sampai tahap uji lapangan. Instrumen yang digunakan dalam mengumpulkan data dalam penelitian ini meliputi lembar validasi, angket kepraktisan, dan tes kemampuan berpikir kritis siswa. Sebelum digunakan ketiga instrumen divalidasi berdasarkan validitas isi oleh ahli yang berkompeten dibidangnya hingga didapatkan instrumen yang valid. Pada instrumen tes kemampuan berpikir kritis siswa juga divalidasi secara empiris yang diujicobakan untuk mengetahui tingkat kevalidan, reliabilitas, tingkat kesukaran, dan daya pembeda dari tiap-tiap butir soal. Instrumen tes kemampuan berpikir kritis yang digunakan setelah dinyatakan valid, reliabel, mempunya tingkat kesukaran sedang, dan mempunyai daya pembeda yang baik. Desain uji lapangan untuk mengukur efektifitas bahan ajar yang dikembangkan digunakan pretest-posttest control grup design. Adapun sampel uji lapangan dipilih dengan teknik cluster random sampling dan diperoleh kelas XI A1 sebagai kelas eksperimen dan XI $\mathrm{A}_{3}$ sebagai kelas kontrol. Perbedaan antara kedua kelompok tersebut adalah perlakuan dalam proses pembelajaran. Kelas eksperimen mendapat perlakuan pembelajaran dengan bantuan bahan ajar geometri transformasi yang dikembangkan dan kelas kontrol mendapat perlakuan pembelajaran menggunakan bantuan bahan ajar buku kurikulum 2013 terbitan swasta yang biasa digunakan oleh siswa pada pembelajaran sebelumnya.

Dalam penelitian ini dilakukan tiga buah analisis, yaitu analisis kevalidan bahan ajar, analisis kepraktisan bahan ajar, dan analisis keefektifan bahan ajar yang dikembangkan. Analisis kevalidan bahan ajar diperoleh dari data lembar validasi yang diisi oleh para ahli dan analisis kepraktisan bahan ajar dilihat dari angket respon siswa. Total skor yang diperoleh dari masing-masing instrumen dianalisis dengan cara konversi menggunakan rumus $p=\frac{\sum x_{i}-\min }{m g k s-\min } \times 100 \% \quad p=\frac{\sum x_{i}-\min }{\operatorname{maks}-\min } \times 100 \%$ dan diinterprestasikan menggunakan tabel tingkat kepraktisan dan kevalidan bahan ajar yang diadaptasi dari tabel konversi skor (Arikunto, 2010) sebagai berikut.

Tabel 1. Tingkat Kepraktisan dan Kevalidan Bahan Ajar

\begin{tabular}{ccc}
\hline $\begin{array}{c}\text { Tingkat } \\
\text { Pencapaian }\end{array}$ & Kriteria Valid & Kriteria Praktis \\
\hline $80-100$ & Sangat Valid & Sangat praktis \\
$66-79$ & Valid & Praktis \\
$56-65$ & Cukup valid & Cukup praktis \\
$40-55$ & Kurang valid & Kurang praktis \\
$0-39$ & Sangat & Sangat Kurang \\
& Kurang & \\
\hline
\end{tabular}

Pembelajaran yang efektif ditijau dari tujuan pembelajaran adalah tercapainya hasil belajar yang baik. Dalam penelitian ini hasil belajar diukur dengan instrumen tes kemampuan berpikir kritis siswa. Karena diperoleh data rata-rata hasil posttest kemampuan berpikir kritis siswa dari kedua kelompok berdistribusi normal dan homogen dan diperoleh data rata-rata $\mathrm{N}$-gain dari kedua kelompok berdistribusi normal maka pada analisis efektifitas pembelajaran menggunakan uji t (one sample t-test dan independent sample t-test). Berikut indikator bahwa bahan ajar dinyatakan efektif: (1) Rata-rata hasil posttest kelompok yang belajar menggunakan bahan ajar yang dikembangkan lebih besar dari nilai KKM yakni 76. (2) Rata-rata hasil posttest kelompok yang belajar menggunakan bahan ajar yang dikembangkan lebih besar daripada rata-rata nilai posttest kelompok yang belajar menggunakan buku cetak kurikulum 2013. (3) Ratarata $\mathrm{N}$-gain kelompok yang belajar menggunakan bahan ajar yang dikembangkan dalam kriteria minimal sedang atau lebih besar dari 0.30, dan (4) rata-rata $\mathrm{N}$-gain kelompok yang belajar menggunakan bahan ajar yang dikembangkan lebih besar daripada rata-rata $N$-gain kelompok yang belajar menggunakan buku cetak kurikulum 2013. 


\section{HASIL DAN PEMBAHASAN}

Bahan ajar transformasi geometri yang dikembangkan merupakan perangkat pembelajaan utama yang dihasilkan. Kemampuan siswa dalam menyelesaikan masalah berpikir kritis materi transformasi geometri menjadi tolak ukur dalam penelitian ini. Tahapan-tahapan yag dilakukan untuk menghasilkan bahan ajar transformasi geometri dijelaskan sebagai berikut. Studi pendahuluan dan pengumpulan data bertujuan untuk melihat masalah yang terjadi di lapangan, keadaan sekolah, aktivitas siswa selama proses pembelajaran. Didapatkan data bahwa guru masih menggunakan metode pembelajaran yang konvensional dalam pembelajaran matematika, hanya siswa yang memiliki kemampuan berpikir tinggi yang mampu terlibat aktif dalam pelajaran, sedangkan siswa lainnya hanya berdiam diri tanpa ingin mencoba menyelesaikan soal yang diberikan, siswa kesulitan dalam menginformasikan jawaban dari suatu persoalan, buku cetak yang tersedia tidak mengarahkan keaktifan belajar siswa, dan belum sesuai dengan karakteristik serta situasi siswa atau mendorong keaktifan serta tumbuhnya kemampuan berpikir kritis siswa sehingga siswa masih menerima konsep dalam bentuk final dan menghafalnya. Analisis terhadap siswa didapatkan informasi siswa mampu berpikir secara abstrak, dengan bantuan permasalahan yang konkreat dan melekat dengan kehidupan siswa. Analisis terhadap materi dilakukan dengan penjabaran materi dari kompetensi dasar yang harus dikuasai siswa ke dalam materi dan indikator pencapaian.

Penyusun rancangan bahan ajar geo- metri transformasi dilakukan sesuai dengan analisis kebutuhan. Bahan ajar yang dibuat terdiri dari bagian pembuka, terdiri dari judul, daftar isi, mind map, kompetensi dasar dan tujuan pembelajaran, dengan harapan bahwa siswa memahami kompetensi yang akan mereka kuasai atau memahami arah dari pembelajaran yang akan berlangsung sehingga siswa tidak tersesat dalam mengembangkan kemampuannya dengan mengkaji sumbersumber belajar lainnya.

Pada bagian isi dikembangkan materi dengan tahapan-tahapan pemecahan masalah yang dikembangkan dengan berorientasi pada kemampuan berpikir kritis yaitu (a) memberikan masalah konkreat dengan harapan bahwa siswa mendapatkan situasi yang tidak rutin atau tidak dapat secara langsung diketahui bagaimana cara menentukan solusi dari masalah matematis yang dihadapi. Tahapan ini berlandaskan pada pendapat Maulauna (2017) bahwa kemampuan berpikir kritis dapat berkembang jika siswa dihadapkan pada situasi yang tidak familiar dalam hal ini adalah permasalahan yang tidak langsung dapat diselesaikan atau ditebak dengan langkah pendek penyelesaiannya, namuh harus melalui beberapa tahapan pemikiran. Berikut ini contoh pengembangan bahan ajar pada tahap memberikan masalah konkret.

(b) Pada tahap memahami masalah dihadirkan situasi yang memberikan kesempatan siswa untuk dapat menggunakan pengetahuan yang dimiliki agar terjadi penalaran matematis, yaitu proses mengidentifikasi permasalahan dan menentukan prioritas (Fa-

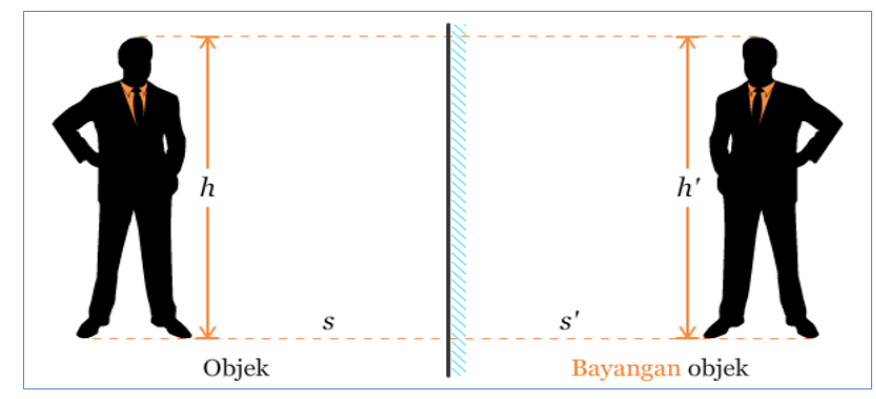

Gambar 3.1 Objek Di Depan Cermin

Pencerminan dalam kehidupan sehari-hari dapat digambarkan melalui sistem koordinat, bagaimana caranya? Apa saja yang dapat digambarkan?

Gambar 1. Fenomena yang Dihadirkan dalam Bahan Ajar 


\section{- Pada permainan catur sebuah kuda hitam sebelah kiri pada papan awal permainan catur hanya dapat berpindah ke posisi $A$ atau posisi $\boldsymbol{B}$ karena aturan permainan catur. \\ - Sebuah pion hitam paling kanan pada awal permainan hanya dapat berpindah ke posisi $\mathrm{K}$ atau posisi $\mathrm{L}$, karena aturan permainan catur.

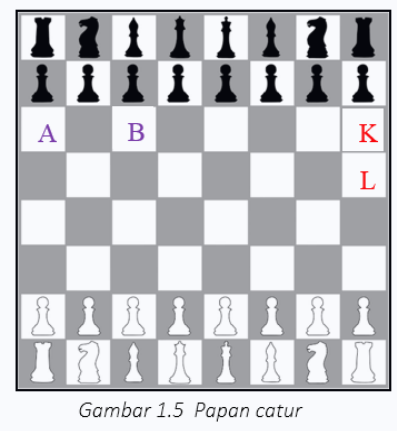 \\ - Bagaimana bentuk dan ukuran kuda dan pion setelah berpindah? Tetap atal berubah? \\ Gambar 2. Bagian Bahan Ajar yang Melatih Penalaran Matematis}

cione 2010). Tahapan ini dikembangkan dengan dasar pendapat Ennis (1993) bahwa mengidentifikasi alasan, asumsi, dan kesimpulan merupakan kriteria yang harus dilakukan oleh seseorang dalam berpikir kritis. Mengkaji sebab-sebab atau akibat-akibat yang terjadi dari hasil analisis yang harus dilakukan oleh siswa pada tahap ini. Berikut ini contoh pengembangan bahan ajar pada tahap memberikan masalah konkreat.

(c) Membuat rencana merupakan tahapan hasil dari proses mengkaji sebab-sebab dan kaitan-kaitan permasalahan yang ada dalam kenyataanya. Pengembangan tahap ini didasarkan pada pendapat Facione (2010) bahwa merencanakan pilihan penyelesaian dan mempertimbangkan konsekuensi yang muncul merupakan langkah penyelesaian masalah yang berdasarkan berpikir kritis. Sis- wa juga harus berdasarkan aturan dan sistem yang menjadi akar dari permasalahan serta mempertimbangkan konsekuensi yang muncul. Berikut ini contoh pengembangan bahan ajar pada tahap membuat rencana.

(d) Melaksanakan rencana dengan melaksanakan strategi yang telah disusun dan melakukan perhitungan yang harus berlangsung dan mempertahankan rencana yang sudah dipilih. Menurut Ennis (1996) mengadakan eksperimen, menginformasikan dengan baik, mengembangkan dan mempertahankan dan mempertahankan posisi pada pokok masalah merupakan kriteria yang harus dilakukan dalam berpikir kritis. Pada tahap ini siswa diajak berproses mengikuti sistem atau aturan-aturan dalam perhitungan matematika dan menarik kesimpulan dengan hatihati. Maulana (2017) juga berpendapat bah-

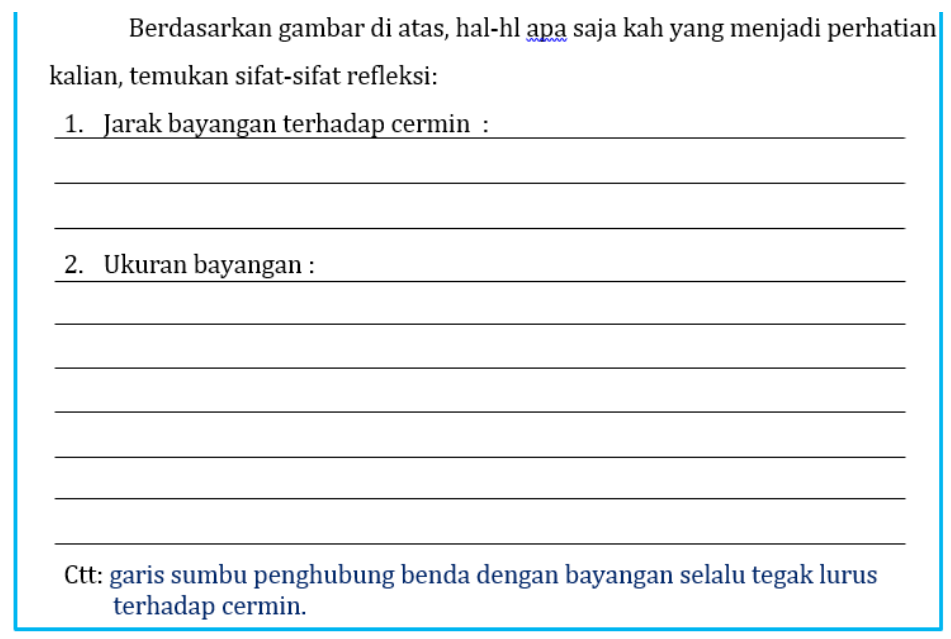

Gambar 3. Bagian Bahan Ajar yang Mengkaji Sebab-Sebab 


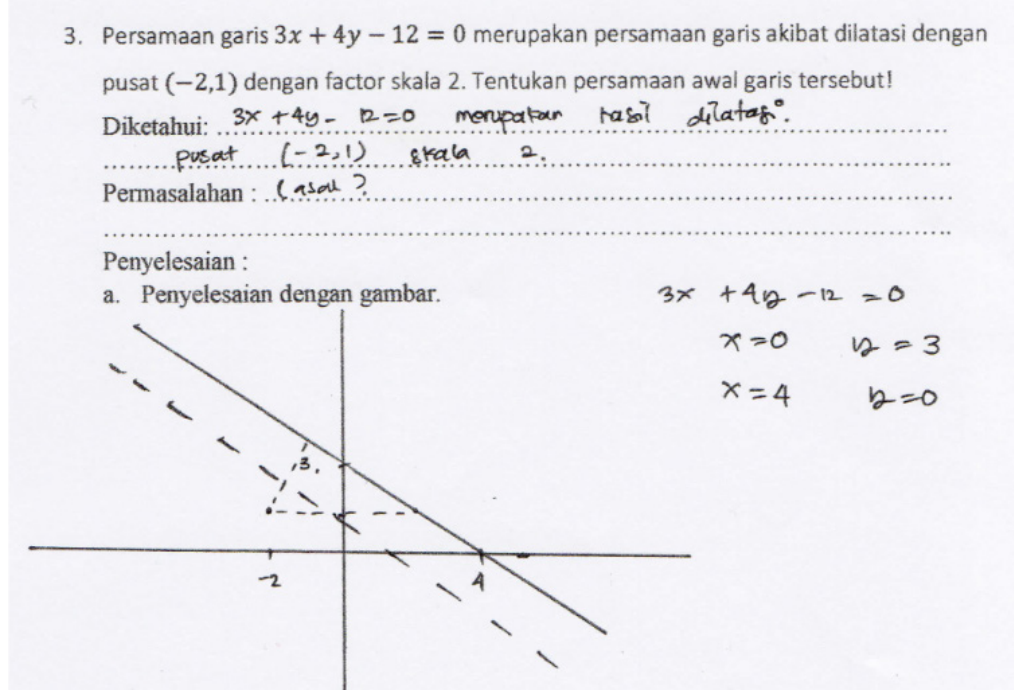

Gambar 4. Bagian Bahan Ajar yang Menampilkan Proses Pekerjaan Siswa

wa memberikan kesempatan kepada siswa untuk melakukan generalisasi, pembuktian, dan evaluasi terhadap situasi matematis dan proses pencarian solusi yang telah dilakukan dengan penuh perhitungan merupakan salah satu kondisi untuk terjadinya berpikir kritis. Berikut ini contoh pekerjaan siswa pada pengembangan bahan ajar tahap melaksanakan rencana.

(e) Melihat kembali dengan bertanya kepada diri sendiri apakah pertanyaannya sudah benar-benar terjawab serta meneliti proses dan mengoreksi seperlunya merupakan tahapan akhir pada setiap subbab dalam bahan ajar yang menekankan pada situasi dimana siswa diajak untuk lebih yakin dengan hadirnya penjelasan mengenai uraian materi secara detail dengan pembuktian serta alasan yang logis. Tahapan ini merupakan tahap ak- hir dalam pemecahan masalah menurut Polya (1980) yakni melihat kembali hasil yang diperoleh.

Bagian penutup, terdiri dari tes akhir dan umpan balik. Pada setiap indikator pencapaian dikembangkan fenomena yang berkaitan dengan materi dan yang dapat dianalisis dan dilogika oleh perserta didik. Pada tahap ini pengembangan kemampuan berpikir kritis pada proses pemecahan masalah didesain dalam pembelajaran berjalan beriringan. Kemampuan berpikir kritis yang dikembangkan sesuai dengan pendapat Facione (2010) yakni: Interpretation merupakan kemampuan seseorang untuk memahami dan menyatakan arti atau maksud dari pengalaman yang bervariasi situasi, data, peristiwa, keputusan, konvensi, kepercayaa aturan, prosedur atau kriteria. Analysis kemampuan untuk mengidentifikasi

Jarak dari titik $P(x, y)$ kegaris $x=a$ sebagai cermin adalah $d=x-a$.

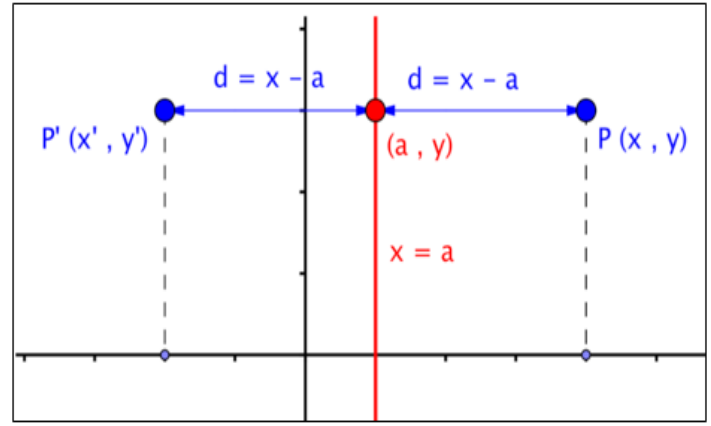

Gambar 3.6 Refleksi terhadap Garis $x=a$

Gambar 5. Bagian Bahan Ajar yang Mengklarifikasi Pemahaman Siswa 
maksud dan kesimpulan yang benar antara pernyataan, pertanyaan, konsep, deskripsi berdasarkan kepercayaan, keputusan, pengalaman, alasan, informasi atau pendapat. Evaluation kemampuan menilai kredibiitas pernyataan atau penyajian lain dengan menilai atau menggambarkan persepsi seseorang, pengalaman, situasi, kepercayaan, keputusan dan menggunakan kekuatan logika dari hubungan inferensial yang diharapkan atau hubungan inferensial yang aktual diantara pernyataan, pertanyaan, deskripsi maupun bentuk representasi lainya. Inference adalah kemampuan siswa untuk mengidentifikasi dan memilih unsur-unsur yang diperlukan untuk membentuk kesimpulan yang beralasan atau untuk membentuk kesimpulan yang beralasan atau untuk membentuk hipotesis dengan memperhatikan informasi relevan dan mengurangi konsekuensi yang ditimbulkan dari data, pernyataan, prinsip, bukti, penilaian, opini, deskripsi, penyataan, keyakinan, maupun bentuk representasi lainnya. Explanation kemampuan seseorang untuk menyatakan hasil proses pertimbangan, kemampuan untuk membenarkan bahwa suatu alasan itu berdasarkan bukti, metodologi, konsep, atau suatu kriteria tertentu dan pertimbangan yang masuk akal, dan kemampuan untuk mempresentasikan alasan berupa argumen yang meyakinkan.

Tahap berikutnya adalah melakukan validasi oleh ahli media dan ahli materi. Bahan ajar yang telah disusun diserahkan kepada ahli para ahli dengan menyertakan lembar penilaian. Validator dalam penelitian ini adalah dosen MIPA Universitas Lampung bapak Suharsono S., M.S., M.Sc., Ph.D dan praktisi lapangan C. Ike Tri Widyastuti. M.Si sebagai ahli materi, dosen pascasarjana Universitas Lampung yaitu bapak Dr. Budi Koetoro, M.Pd dan Adi Prabowo M.Pd sebagai ahli media dan guru pengampu pelajaran matematika kelas XI SMA Fransiskus Bandar Lampung. Berikut perhitungan rekapitulasi validasi oleh validator.

Perolehan skor hasil validasi bahan ajar transformasi geometri oleh ahli materi dan ahli media diinterperestasikan menggunakan tabel tingkat kevalidan dan revisi produk yang diadaptasi dari tabel konversi skor (Arikunto, 2010) dan mendapat pencapaian dari ahli materi sebesar 86 dan dari ahli media 83 dalam kriteria sangat baik, sehingga bahan ajar dinyatakan valid. Saran dan masukan dari validator dipergunakan sebagai bahan pertimbangan untuk melakukan revisi tahap pertama dengan tujuan untuk menyempurnakan rancangan produk awal.

Tahap uji coba awal dilakukan sesuai perencanaan pada pembelajaran dan bahan ajar diberikan kepada setiap siswa kelas XI $\mathrm{A}_{4}$. Kelas tersebut belum melakukan proses pembelajaran transformasi geometri. Siswa kelas $\mathrm{XI} \mathrm{A}_{4}$ memiliki kemampuan yang heterogen. Uji coba ini bertujuan untuk memastikan bahwa bahan ajar dapat memfasilitasi siswa di kelas yang berkemampuan heterogen yakni yang berkemampuan tinggi, sedang, dan rendah. Analisis respon siswa dilakukan sebagai pertimbangan dalam revisi tahap kedua dan untuk mendapatkan produk yang lebih baik.

Dalam uji lapangan, bahan ajar digunakan pada pembelajaran di kelas untuk mengetahui keefektifannya dalam memfasilitasi kemampuan berpikir kritis siswa. Bahan ajar yang dikembangkan digunakan di kelas XI A1 SMA Fransiskus Bandar Lampung dengan siswa yang berjumlah 33 orang. Terdiri dari 18 siswa perempuan dan 15 siswa laki-laki yang memiliki kemampuan heterogen. Pembelajaran dilaksanakan dalam tujuh kali pertemuan atau empat belas jam pelajaran.

Analisis kepraktisan dilakukan dengan melihat hasil angket respon siswa pada kelas eksperimen sebagai berikut.

Tabel 2. Hasil Validasi Bahan Ajar

\begin{tabular}{lcllcc}
\hline \multicolumn{3}{c}{ Ahli Materi } & & \multicolumn{3}{c}{ Ahli Media } \\
\hline \multicolumn{1}{c}{ Aspek Penialian } & Skor & Interprestasi & Aspek Penialian & Skor & Interprestasi \\
\hline Kesesuaian konsep & 94 & Sangat Valid & Kualitas tapilan & 75 & Valid \\
Kedalaman konsep & 83 & Sangat Valid & Kesesuaian Ilustrasi & 78 & Valid \\
Penggunaan bahasa & 83 & Sangat Valid & Kesesuaian materi & 100 & Sangat Valid \\
\hline Total & 86 & Sangat Valid & Total & 83 & Sangat Valid \\
\hline
\end{tabular}


Tabel 3. Hasil Angket Respon Siswa

\begin{tabular}{ccccc}
\hline Aspek Penialian & Skor & Skor Maks & Skor Konversi & Kriteria \\
\hline Aspek Tampilan & 669 & 825 & 67 & (baik) \\
Aspek Penyajian Materi & 1259 & 1650 & 70 & (baik) \\
Aspek Manfaat & 1929 & 2475 & 72 & (baik) \\
\hline Total Skor & 3795 & 4950 & 71 & (baik) \\
\hline
\end{tabular}

Tabel 4. Analisi Hasil Posttest Kemampuan Berpikir Kritis

\begin{tabular}{ccccc}
\hline one sample t-test & $\mathrm{t}$ & $\mathrm{df}$ & Mean Difference & Sig. \\
\hline Posttest Eksperimen & 2,161 & 32 & 1,636 & 0,019 \\
independent sample t-test & Kelompok & Mean & Std. Dev & Sig. \\
& Ekperimen & 77,64 & 4,350 & 0.001 \\
\hline
\end{tabular}

Tabel 5. Hasil Uji t Indeks Gain

\begin{tabular}{ccccc}
\hline one sample t-test & $\mathrm{t}$ & $\mathrm{df}$ & Mean Difference & Sig. \\
\hline Posttest Eksperimen & 43,734 & 32 & 0,377 & 0,000 \\
independent sample t-test & Kelompok & Mean & Std. Dev & Sig. \\
& Ekperimen & 0,71 & 0,04 & 0,000 \\
\hline
\end{tabular}

Berdasarkan Tabel 3 terlihat bahwa pencapaian total skor tingkat kepraktisan sebesar 71 dalam kriteria baik dan semua aspek penilaian dalam kriteris baik. Dari hasil analisi angket respon siswa diperoleh data 25 siswa dari 33 siswa menyatakan bahwa bahan ajar transformasi geometri praktis dalam kategori minimal baik. Sehingga dapat disimpulkan bahwa bahan ajar transformasi geometri yang dikembangkan praktis dalam penggunaannya.

Analisis kemampuan akhir berpikir kritis siswa diperoleh dari hasil posttest yang digunakan untuk melihat pebedaan kemampuan berpikir kritis siswa pada kedua kelompok setelah pembelajaran.

Berdasarkan Tabel 4 terlihat bahwa rata-rata hasil belajar siswa pada kelompok yang belajar menggunakan bahan ajar yang dikembangkan lebih dari 76, pernyataan ini telah dibuktikan secara statistik dengan one sample t-test. Dan untuk membuktikan pernyataan bahwa rata-rata hasil posttest siswa kelompok yang belajar menggunakan bahan ajar yang dikembangkan lebih besar daripada rata-rata kelompok yang belajar menggunakan buku kurikulum 2013 terbitan swasta, dilakukan uji kesamaan dua rata-rata dengan independent sample t-test diperoleh hasil probabilitas (Sig.) 0.001 yakni kurang dari 0,05, sehingga dapat disimpulkan bahwa rata-rata skor posttest siswa kelompok yang belajar menggunakan bahan ajar yang dikembangkan lebih besar dari rata-rata skor posttest kelompok yang belajar menggunakan buku kurikulum 2013 terbitan swasta.Untuk melihat kemampuan siswa dari awal sampai setelah pembelajaran dilakukan analisis indeks gain kemampuan berpikir kritis siswa dari hasil pretest dan posttest.

Berdasarkan Tabel 3 indeks gain pada kelompok yang belajar menggunakan bahan ajar yang dikembangkan lebih besar dari 0.3, pernyataan ini telah dibuktikan secara statistik dengan one sample t-test. Selanjutnya dilakukan uji kesamaan dua rata-rata yakni independent sample t-test untuk membuktikan pernyataan rata-rata indeks gain siswa kelompok yang belajar menggunakan bahan ajar yang dikembangkan lebih besar daripada rata-rata indeks gain kelompok yang belajar menggunakan buku kurikulum 2013 terbitan swasta. Diperoleh hasil nilai probabilitas (Sig.) 0,000 kurang dari 0,05 sehingga dapat disimpulkan bahwa indeks gain pada siswa kelompok yang belajar menggunakan bahan ajar yang dikembangkan lebih tinggi dibandingkan dengan indeks gain pada kelompok yang belajar menggunakan buku kurikulum 2013 terbitan swasta, dengan kata lain bahan ajar transformasi geometri yang dikembangkan efektif untuk meningkatkan kemampuan berpikir kritis siswa.

Analisis penyebab adanya perbedaan 
kemampuan berpikir kritis siswa pada kedua kelompok adalah karena adanya pemberlakuan yang berbeda, yakni penggunaan bahan ajar transformasi geometri yang dikembangkan. Kelebihan bahan ajar transformasi geometri dapat dilihat pada proses pembelajaran yakni siswa menjadi lebih aktif karena memiliki bahan ajar yang mampu memfasilitasi siswa untuk bertanya dan menyimak. Analisis penyebab adanya perbedaan kemampuan berpikir kritis siswa pada kelompok yang menggunakan bahan ajar transformasi geometri yang dikembangkan dengan kelompok yang menggunakan buku cetak kurikulum 2013 terbitan swasta setelah pembelajaran karena ketika menggunakan bahan ajar, siswa dibiasakan dengan permasalahan-permasalahan menantang sehingga memunculkan konflig kognitif dalam diri siswa yang merangsang siswa untuk melakukan ekplorasi dan menyelidiki pemecahan masalah tersebut.

Pada saat pemecahan masalah siswa terlatih untuk menggali ide-ide dan membangun pengetahuan secara mandiri tanpa tergantung pada guru. Sehingga bahan ajar memberikan kesempatan bagi siswa dalam membangun kemampuan berpikir kritisnya. $\mathrm{Hal}$ ini sejalan dengan pendapat Maulana (2017) bahwa kondisi untuk terjadinya proses berpikir kritis matematis harus memuat halhal berikut ini. (1) Situasi yang tidak familiar, dalam hal ini siswa tidak dapat secara langsung mengetahui bagaimana menentukan solusi dari masalah matematis yang dihadapi. (2) Memberikan kesempatan kepada siswa untuk menggunakan pengetahuan awalnya, melakukan penalaran matematis, dan mencoba strategi kognitif secara fleksibel. (3) Memberikan kesempatan kepada siswa, untuk melakukan generalisasi, pembuktian, dan evaluasi terhadap situasi matematis dan proses pencarian solusi yang telah dilakukannya dengan penuh pertimbangan.

Kelebihan bahan ajar transformasi geometri dapat dilihat pada proses pembelajaran yakni siswa menjadi lebih aktif karena memiliki bahan ajar yang mampu memfasilitasi siswa untuk bertanya dan menyimak. Pada contoh soal dan latihan soal siswa dapat lebih mudah memahami karena memiliki sumber belajar yang runtut dan sistematis sesuai dengan pro- ses pembelajaran yang mereka jalani. Seperti yang diungkapkan Happy \& Widjajanti (2014) lemahnya kemampuan berpikir kritis dan kreatif matematis siswa dapat disebabkan oleh beberapa faktor. Salah satu diantaranya adalah proses pembelajaran yang dilaksanakan. Pembelajaran matematika haruslah melibatkan siswa secara aktif serta memfasilitasi siswa untuk dapat menggunakan kemampuan berpikir kritisdan kreatifnya.

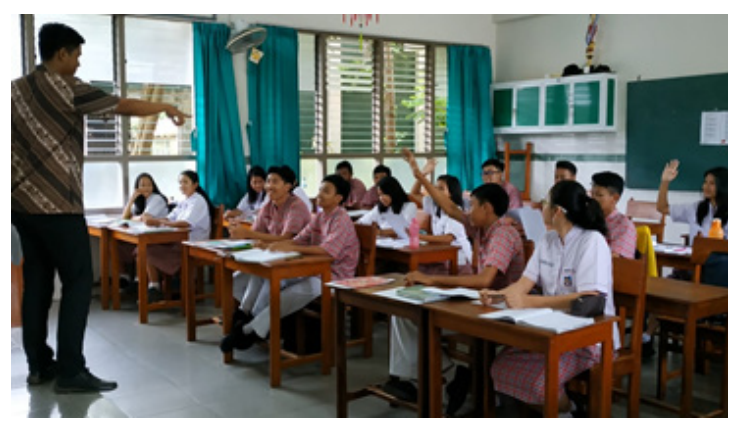

Gambar 6. Siswa Aktif Dalam Bertanya dan Menjawab Pertanyaan

Penjelasan-penjelasan yang dilakukan oleh pendidik juga termuat dalam bahan ajar sehingga pada proses pembelajaran siswa memiliki bahan untuk dapat menyimak, sehingga pembelajaran lebih banyak berpusat pada siswa dan menuntut siswa untuk memahami permasalahan yang dipersiapkan oleh guru secara lebih mendetail menurut Adhiwibowo (2018). Jika siswa kurang memahami penjelasan pendidik mereka dapat mengulangi proses pemahaman materi dengan bantuan bahan ajar yang mereka miliki.

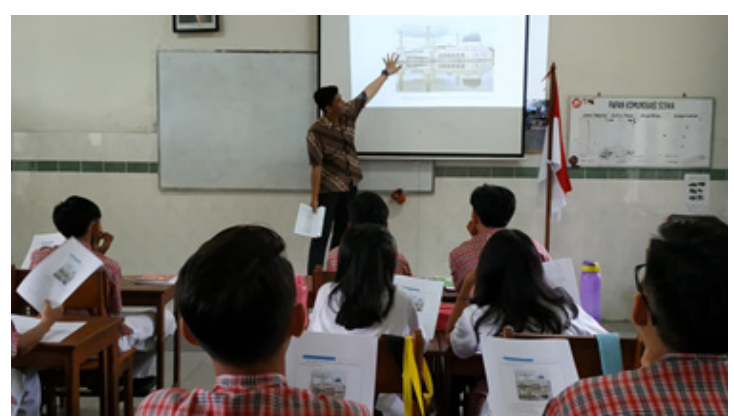

Gambar 7. Media Pembelajaran Bersumber Dari Bahan Ajar

Media pembelajaran yang digunakan oleh pendidik juga bersumber dari bahan ajar yang telah dikembangkan, sehingga pada proses pembelajaran siswa tidak lagi membu- 


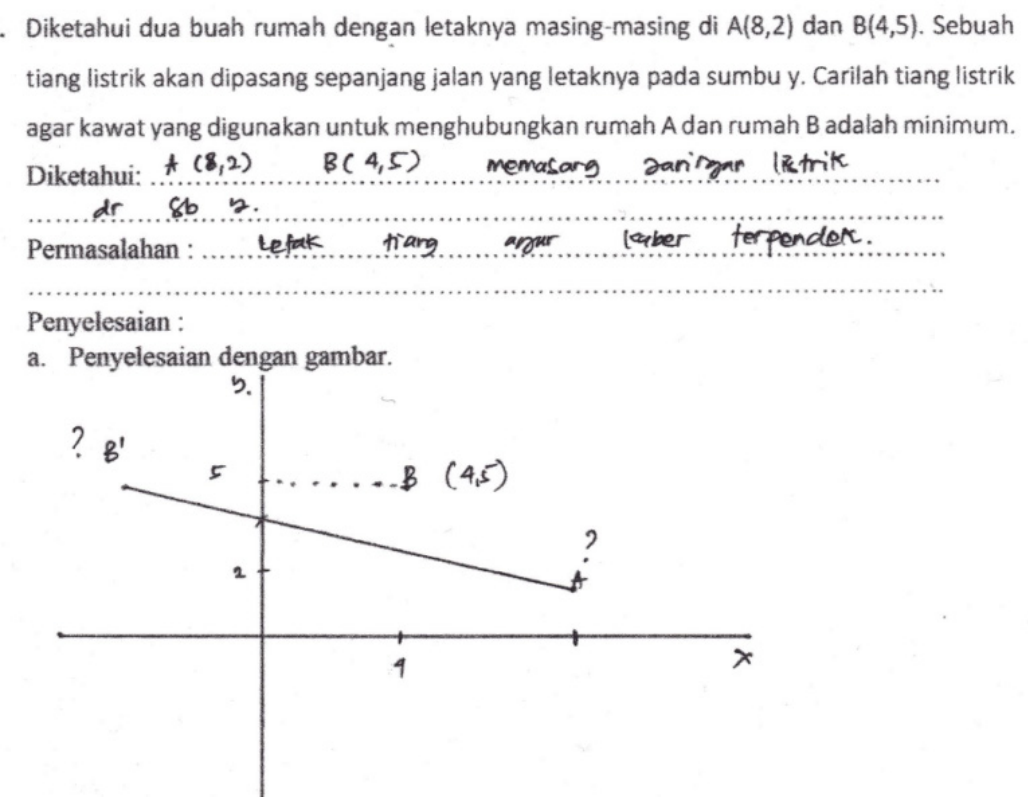

Gambar 8. Bahan Ajar Menuntut Siswa Mengilustrasikan Soal

tuhkan waktu yang panjang untuk mendokumentasikan ulang penjelasan pendidik seperti pada pembelajaran konvensional, siswa cukup menambahkan pada bagian-bagian yang dirasa perlu oleh siswa untuk ditambahkan. Atau bahkan siswa dapat langsung melakukan kegiatan selanjutnya yakni latihan soal.

Perbedaan kemampuan berpikir kritis juga terlihat dari hasil posttest kemampuan berpikir kritis peseta didik yang dikarenakan pada proses berbantu bahan ajar siswa dibiasakan untuk tersistem melalui tahapantahapan pada kemampuan berpikir kritis baik dalam contoh soal, penjelasan-penjelasan materi, dan juga pada saat siswa dituntut untuk dapat mengerjakan latihan soal.

Siswa selalu diajak untuk dapat mengilustrasikan permasalahan soal, memahami permasalahan soal, memprediksi penyelesaian atau solusi dari permasalahan dan memberikan alasan serta mengecek kembali sehingga didapatkan sesuai dengan hasil yang diharapkan. Hal ini senada dengan pendapat dengan pendapat Nickerson (1987) yang menyatakan bahwa kemampuan berpikir kritis dalam pembelajaran dapat dikembangkan dengan asumsi bahwa umunnya siswa dapat mencapai kemampuan berpikir kritis dengan diajarkan dan dapat dipelajari. Seperti yang diungkapkan oleh Johnson (2002) bahwa jika siswa diberi kesempatan untuk melatih ke- mampuan berpikirnya, nantinya akan terbentuk suatu kebiasaan untuk dapat membedakan antara benar dan tidak benar, dugaan dan kenyataan, fakta dan opini, serta pengetahuan dan keyakinan. Dengan demikian siswa secara alami akan dapat membangun argumen yang didasari bukti logis dan terpercaya.

\section{SIMPULAN}

Kesimpulan yang diperoleh dalam penelitian ini adalah dihasilkan bahan ajar transformasi geometri yang berorientasi pada kemampuan berpikir kritis siswa. Bahan ajar transformasi geometri yang dikembangkan dinyatakan valid dalam kriteria sangat baik, praktis dalam kriteria baik, serta efektif dalam meningkatkan kemampuan berpikir kritis.

\section{DAFTAR PUSTAKA}

Adhiwibowo, B., \& Karyati, (2018), Pengembangan Perangkat Pembelajaran Berbasis Masalah Berorientasi pada Kreativitas Matematis. Kreano Jurnal Matematika Kreatif-Inovatif. 9 (2) 174-183

Arikunto, S. (2010). Dasar-Dasar Evaluasi Pendidikan. Jakarta: Bumi Aksara.

Borg, W.R. \& Gall, M.D. (1989). Educational Research: An Introduction, (Fifth Edition). New York: Longman.

Budiman, I, Sukandi, A, Setiawan, A. (2008). Model Pembelajaran Multimedia Interaktif Dualisme Gelombang Partikel untuk Meningkatkan Pemahaman Konsep dan Ketertampilan Berfikir Kritis. Jurnal Penelitian Pendidikan IPA, 2 (1).

Ennis, R.H. (1993). Critical Thinking Assessment. Journal of Theory Into Practice - The Ohio State University 32(3), 179-186. 
Ennis, R.H. (1996). Critical Thinking. New Jersey. Prentice-Hall Inc.

Facione, A.P. (2010). Holistic Critical Thinking Scoring Rubric. California Academia Press, San Francisco. The Journal of Human Resource and Adult Learning, 4(1).

Happy, N., \& Widjajanti, D.B. (2014) Keefektifan PBL Ditinjau dari Kemampuan Berpikir Kritis dan Kreatif Matematis, serta Self-Esteem Siswa SMP. Jurnal Riset Pendidikan Matematika, 1(1), 48-57.

Hasruddin. (2009). Memaksimalkan Kemampuan Berpikir Kritis melalui Pendekatan Kontekstual. Jurnal Tabularasa PPS Unimed, 6(1): 48-60.

Johnson, E.B. (2002). Contextual Teaching and Learning. Thausand Oaks, California: Corwin Press, Inc. A
Sage Publication Company.

Liberna, H. (2015). Peningkatan Kemampuan Berpikir Kritis Matematis Siswa Melalui Penggunaan Metode Improve Pada Materi Sistem Persamaan Linear Dua Variabel. Formatif: Jurnal Ilmiah Pendidikan MIPA, 2(3).

Maulana, (2017). Konsep Dasar Matematika Dan Pengembangan Kemampuan Berpikir Kritis-Kreatif. Sumedang: UPI Sumedang Press.

Nickerson, R. S.(1987). Why teach thinking? In Teaching Thinking Skills: Theory and Practice. Ed. Joan Boykoff Baron and Robert J. Sternberg. New York: W.H. Freeman \& Co.

OECD. (2016). PISA 2015 Results from PISA 2015. New York: Columbia University 